\title{
Dollar Spot Suppression on Creeping Bentgrass in Response to Repeated Foliar Nitrogen Applications
}

\author{
Ronald Townsend, ${ }^{1}$ Michael D. Millican, ${ }^{2}$ Damon Smith, ${ }^{1}$ Ed Nangle, ${ }^{3}$ Kurt Hockemeyer, ${ }^{1}$ Doug Soldat, ${ }^{4}$ and Paul L. Koch ${ }^{1, \dagger}$ \\ ${ }^{1}$ University of Wisconsin-Madison, Department of Plant Pathology, Madison, WI 53706 \\ ${ }^{2}$ University of Minnesota, Department of Plant Pathology, St. Paul, MN 55108 \\ ${ }^{3}$ The Ohio State University, Wooster Campus, Wooster, OH 44691 \\ ${ }^{4}$ University of Wisconsin-Madison, Department of Soil Science, Madison, WI 53706
}

\begin{abstract}
Dollar spot is caused by the fungus Clarireedia spp. and is the most economically important disease of golf course turfgrass in temperate regions of the United States. Previous research has demonstrated that nitrogen $(\mathrm{N})$ fertilization may reduce dollar spot severity, but the results have been inconsistent, and the impact of $\mathrm{N}$ as part of repeated foliar fertilization applications to golf course putting greens remains unclear. Two independent trials were replicated in Madison, Wisconsin and Glenview, Illinois in the 2015, 2016, and 2017 growing seasons. The objective of the first trial was to evaluate the effect of four different $\mathrm{N}$ rates applied as urea (4.9, $9.8,19.4$, and $29.3 \mathrm{~kg} \mathrm{~N} / \mathrm{ha}$ applied every 2 weeks) on dollar spot severity,

sources (calcium nitrate, ammonium sulfate, and ammonium nitrate applied every 2 weeks) on dollar spot severity. Results from the $\mathrm{N}$ rate trial at both locations indicated that only the highest $(29.3 \mathrm{~kg}$ N/ha) rate consistently reduced dollar spot severity relative to the nontreated control. Nitrogen source had minimal and inconsistent impacts on dollar spot severity based on location and year. Although these results show that meaningful reductions in dollar spot severity can be achieved by manipulating $\mathrm{N}$ fertilizer application rates, the rate of $\mathrm{N}$ needed for disease suppression may be impractical for most superintendents to apply and result in undesirable nontarget impacts.
\end{abstract} and the objective of the second trial was to evaluate the effect of three $\mathrm{N}$
Keywords: dollar spot, fungi, nitrogen, turfgrass
Dollar spot is an economically important foliar disease of golf course turfgrass caused by the fungus Clarireedia spp. (formerly Sclerotinia homoeocarpa) (Salgado-Salazar et al. 2018; Smiley et al. 2005). Dollar spot can occur throughout the growing season, and golf course managers in temperate climates apply more fungicide to control dollar spot than any other turfgrass disease (Smiley et al. 2005; Vargas 1994). Although fungicides are effective and widely used tools for suppressing dollar spot, there are increasing financial, resistance, and environmental concerns related to their continued routine use. The average U.S. golf course uses $5 \%$ of its total budget on fungicides, or an average of $\$ 36,000$ annually, focused mostly on suppressing dollar spot (Golf Course Industry 2015). Documented resistance of Clarireedia to several fungicide classes has been reported, including demethylation inhibitors, benzimidazoles, and succinate dehydrogenase inhibitors (Burpee 1997; Detweiler et al. 1983; Golembiewski et al. 1995; Sang et al. 2015). In addition, numerous human and environmental hazards have been associated with repeated exposures to pesticides, and reviews can be found in Pimentel et al. (1992) and Tomer et al. (2015).

Concerns about reliance on chemical control has led to a wealth of research over several decades focused on cultural control strategies for dollar spot (Walsh et al. 1999). There has been a particular focus on nitrogen $(\mathrm{N})$ rate impacts on dollar spot severity, and most researchers have shown that increasing the $\mathrm{N}$ rate decreases disease severity. Williams et al. (1996) observed decreased dollar spot on

${ }^{\dagger}$ Corresponding author: P. L. Koch; plkoch@wisc.edu

Funding: Funded by the Wisconsin Turfgrass Association, Illinois Turfgrass Foundation, and Midwest Association of Golf Course Superintendents.

*The $\boldsymbol{e}$-Xtra logo stands for "electronic extra" and indicates that one supplementary table is published online.

The author(s) declare no conflict of interest.

Accepted for publication 12 August 2020.

(C) 2021 The American Phytopathological Society
'Penncross' creeping bentgrass (Agrostis stolonifera L.) in Kentucky that was fertilized annually with 36.6 and $73.2 \mathrm{~kg} \mathrm{~N} / \mathrm{ha}$ of granular urea (46-0-0). Golembiewski and Danneberger (1998) also observed decreased dollar spot with higher rates (five monthly applications at 24.4 and $48.8 \mathrm{~kg} \mathrm{~N} / \mathrm{ha}$ ) of granular sulfur-coated urea (21-4-11) applied to fairway height 'Crenshaw' creeping bentgrass in Ohio. Similarly, Landschoot and McNitt (1997) observed decreased dollar spot severity after applications of various fertilizer sources applied four times per year at 24 and $48 \mathrm{~kg}$ N/ha to a 'Penncross' creeping bentgrass putting green in Pennsylvania. However, when the authors specifically compared 24 and $48 \mathrm{~kg} \mathrm{~N} / \mathrm{ha}$ applied as a foliar spray, only the higher rate decreased dollar spot severity.

There is less evidence suggesting that the source of $\mathrm{N}$ fertilizer influences dollar spot severity. Ryan et al. (2011) found slightly lower levels of dollar spot in 1 of 2 years when ammonium sulfate, compared with other $\mathrm{N}$ sources such as ammonium nitrate and calcium nitrate, is used to fertilize a golf course fairway in Maryland. Several other researchers have observed that synthetic $\mathrm{N}$ sources that provide more readily available $\mathrm{N}$ to the turfgrass plant reduce dollar spot relative to slow-release sources such as activated sewage sludge and composts (Landschoot and McNitt 1997; Liu et al. 1995; Markland et al. 1969). On the other hand, Davis and Dernoeden (2002) found no consistent relationship between $\mathrm{N}$ source and dollar spot on a creeping bentgrass fairway in Maryland.

The potential mechanisms of dollar spot response to $\mathrm{N}$ fertilization are unclear but generally fall into three categories: buildup of competitive microbial populations; increased plant growth rate, which results in "escape" from the pathogen; and alteration of foliar or soil $\mathrm{pH}$ that alters pathogen virulence or plant resistance. Fertilization with certain $\mathrm{N}$ sources and composts has been found to increase leaf and thatch microbial populations and decrease dollar spot (Liu et al. 1995; Nelson and Craft 1992), although the authors in both studies were unable to directly correlate microbial populations and disease suppression. Increased plant growth rate after $\mathrm{N}$ fertilization and the ability of the plant to outgrow or "escape" the pathogen has also been proposed by several authors (Landschoot and McNitt 1997; Liu et al. 1995; Markland et al. 1969), although in all these studies dollar spot was still present at unacceptably high levels at higher $\mathrm{N}$ rates. Soil $\mathrm{pH}$ can be decreased after applications of acidifying 
fertilizers such as ammonium sulfate and increased after applications of alkalizing fertilizers such as calcium nitrate (Carrow et al. 2007; Ma et al. 1990; Pierre 1928). Certain turfgrass diseases such as summer patch (Magnaporthiopsis poae) and take-all patch (Gaeumannomyces avenae) are known to be more severe at alkaline $\mathrm{pH}$, although pH impact on dollar spot remains largely unknown (Duda 2008; Hill et al. 2001). Ryan et al. (2011) tested several different $\mathrm{N}$ sources with different $\mathrm{pH}$ effects and concluded that the acidifying ammonium sulfate applications slightly reduced dollar spot, although the impact on disease was small relative to other $\mathrm{N}$ sources, and other studies have shown no $\mathrm{pH}$ effect on dollar spot (Markland et al. 1969).

Each study discussed so far, with the exception of the urea treatment in Landschoot and McNitt (1997) and Ryan et al. (2011), investigated the impact of four or five applications of primarily granular fertilizer on dollar spot development. However, most golf course superintendents today apply fertilizer by using a "spoonfeeding" approach. This approach focuses on foliar (i.e., liquid applied) fertilizer applications at small rates of $\mathrm{N}$ ( 4.9 to $9.8 \mathrm{~kg} \mathrm{~N} / \mathrm{ha}$ ) made every 7 to 14 days throughout the growing season (Carrow et al. 2007; Dernoeden 2002). This approach allows the turfgrass plant to quickly absorb $\mathrm{N}$, and the frequent low rates of $\mathrm{N}$ promote uniform growth and consistent playing conditions with minimal N leaching (Dernoeden 2002; Liu and Hull 2009; Stiegler et al. 2011). To our knowledge only Ryan et al. (2011) have investigated $\mathrm{N}$ impacts on dollar spot development by using a spoonfeeding, foliar-applied approach.

The objectives of this research were to assess the impact of various $\mathrm{N}$ rates on dollar spot development by using repeated (14-day) applications of foliar, liquid-applied urea and to evaluate dollar spot severity in response to different synthetic $\mathrm{N}$ sources that have acidifying, neutralizing, or alkalizing effects on soil $\mathrm{pH}$. Our hypothesis was that dollar spot severity would decrease in a dose-dependent manner with increasing $\mathrm{N}$ application rate and that no consistent $\mathrm{N}$ source impact on dollar spot severity would be observed.

\section{Materials and Methods}

Experimental design and treatment applications. Two independent trials were replicated at the O.J. Noer Turfgrass Research Facility (OJN) in Madison, Wisconsin and North Shore Country Club (NSCC) in Glenview, Illinois during the 2015, 2016, and 2017 growing seasons to investigate the impact of $\mathrm{N}$ fertilizer rate and $\mathrm{N}$ fertilizer source on dollar spot severity. All plots were arranged in a randomized complete block design with four replications. Trials at both locations were conducted on creeping bentgrass putting greens (Agrostis stolonifera cultivar 'Penncross') grown on a sand-based rootzone with U.S. Golf Association specifications and mowed 5 days a week to a height of $3.2 \mathrm{~mm}$ and irrigated to replace evapotranspiration. Clippings were collected and removed during each mowing. Individual treatment plots measured $1.8 \times 1.2 \mathrm{~m}$, and initial applications at both sites for both the $\mathrm{N}$ rate and $\mathrm{N}$ source trials were made on 17 June 2015, 20 May 2016, and 15 May 2017. Subsequent applications were made every 2 weeks, with the final application being 30 September 2015, 14 September 2016, and 13 September 2017. Fertilizer and pesticide applications were made with a $\mathrm{CO}_{2}$-pressurized boom sprayer equipped with nozzles pressurized to $275.8 \mathrm{kPa}$. All treatments were agitated by hand and applied in the equivalent of $814 \mathrm{~L}$ water/ha. No nutrients other than the prescribed treatments were applied to either site during the 3-year period. Flutolanil ( $N$-[3(1-methylethoxy) phenyl]-2-(trifluoromethyl) benzamide) was applied on 29 July 2016 and 4 August 2017 to suppress Rhizoctonia solani outbreaks during the 2016 and 2017 growing seasons at NSCC but is not labeled for and has no documented impact on dollar spot development. The positive control fungicide program was the same for all trials and was designed based on commonly used fungicides in the Midwestern United States to control dollar spot (Table 1). All fungicides were applied based on label recommendations for dollar spot control.

To assess the impact of $\mathrm{N}$ rate on dollar spot development, four $\mathrm{N}$ application rates $(4.9,9.8,19.4$, and $29.3 \mathrm{~kg} \mathrm{~N} / \mathrm{ha})$ were applied every 2 weeks as a foliar urea spray. In addition, there was a nonfertilized control treatment that received only water and a positive control treatment that received a fungicide program but no nitrogen fertilization. A total of 10 applications were made over the course of each season for a total of 49, 99, 194, and $293 \mathrm{~kg} \mathrm{~N} / \mathrm{ha}$ total $\mathrm{N}$ applied annually for each respective $\mathrm{N}$ treatment. The same treatments were maintained on the same plots throughout the 3-year trial.

Adjacent to the $\mathrm{N}$ rate trial at each location was a trial evaluating the impact of $\mathrm{N}$ source on dollar spot severity. Treatments consisted of three synthetic $\mathrm{N}$ sources with different impacts on $\mathrm{pH}$ : calcium nitrate (15.5-0-0) for alkaline, ammonium nitrate (33-0-0) for neutral, and ammonium sulfate (21-0-0) for acidic effects. There was also a nonfertilized water control and a nonfertilized positive control fungicide program (Table 1). In the 2015 and 2016 seasons these fertilizers were applied at $9.8 \mathrm{~kg} \mathrm{~N} /$ ha every 2 weeks, and 10 applications were made each season for a total of $98 \mathrm{~kg} \mathrm{~N} / \mathrm{ha}$. The application rates were increased to $29.3 \mathrm{~kg} \mathrm{~N} /$ ha every 2 weeks in 2017 after results from the nitrogen rate study showed reduced dollar spot severity at the higher $\mathrm{N}$ rate.

Data collection. Dollar spot severity was assessed by counting dollar spot infection centers every 14 days between May and September. Turfgrass quality was also rated visually every 14 days via the National Turfgrass Evaluation Program 1 to 9 rating scale where $1=$ dead/necrotic, $6=$ minimally acceptable, and $9=$ excellent (Lee et al. 2011). Turfgrass quality ratings included combinations of disease, color, density, and uniformity and were always conducted by the same person to avoid interpersonal variation. Normalized difference vegetation index (NDVI) was collected on a 14-day interval to estimate turfgrass color and was measured with a FieldScout TCM 500 NDVI Turf Color Meter (Spectrum Technologies Inc., Plainfield, IL). Three NDVI measurements were taken in each plot and averaged together to provide one value per plot.

Turfgrass foliar $\mathrm{N}$ content was measured monthly from May through September each year. Foliar $\mathrm{pH}$ was collected five times per month: $0,2,5,7$, and 14 days after the fertilizer application. Tissue collection for these measurements was conducted with a walkbehind mower, and clippings were collected as the mower was engaged over the middle of each plot. After collection, the clippings were placed into 0.95 -liter paper bags and stored at $-20^{\circ} \mathrm{C}$ until analysis. Total foliar N content was analyzed by Waypoint Analytical (Richmond, VA) and conducted with a LECO FP528 (LECO Corporation; Saint Joseph, MI) using methods previously established by Saint-Denis and Goupy (2004). Foliar pH was quantified via a method described in Cornelissen et al. (2006) that was modified to

Table 1. Positive control fungicide program used at the O.J. Noer Research Facility in Madison, Wisconsin and North Shore Country Club in Glenview, Illinois from 2015 through 2018

\begin{tabular}{|c|c|c|c|c|c|}
\hline Trade name & Active ingredient & Product rate ${ }^{\mathrm{z}}$ & 2015 & 2016 & 2018 \\
\hline Xzemplar & Fluxapyroxad & 0.24 & 4 June & 18 May & 10 May \\
\hline Banner MAXX & Propiconazole & 0.74 & 29 June & 15 June & 7 June \\
\hline Secure & Fluazinam & 0.80 & 15 July & 28 June & 21 June \\
\hline Xzemplar & Fluxapyroxad & 0.24 & 29 July & 12 July & 5 July \\
\hline $26 \mathrm{GT}$ & Iprodione & 3.44 & 4 September & 9 August & 16 August \\
\hline Secure & Fluazinam & 0.80 & 16 September & 22 August & 30 August \\
\hline Banner MAXX & Propiconazole & 0.74 & 30 September & 8 September & 13 September \\
\hline
\end{tabular}

${ }^{\mathrm{z}}$ Rate of product applied in kilograms of active ingredient per hectare. 
compensate for larger sample volumes. The measurement of foliar $\mathrm{pH}$ was conducted by adding deionized water and turfgrass clippings into a 50-ml conical tube (Globe Scientific, Paramus, NJ). The tubes were then laid on their sides and shaken at $200 \mathrm{rpm}$ for $2 \mathrm{~h}$ with an orbital shaker. The samples were then centrifuged at 2,000 rpm for 15 min. The substrate $\mathrm{pH}$ was then measured and recorded with a benchtop $\mathrm{pH}$ meter.

Data analysis. Dollar spot infection center data from each site $(P<$ $0.001)$ and year within each site $(P<0.001)$ were analyzed separately to account for significant differences between year and site. The area under the disease progress curve (AUDPC) was calculated via the trapezoidal method (Campbell and Madden 1990) and standardized based on the length of the epidemic in each year and at each location. Data were subjected to analysis of variance and means separated via Fisher's least significant difference $(P \leq 0.05)$ in the R statistical computing environment. The NDVI data were also subjected to analysis of variance and means separated via Fisher's least significant difference $(P \leq 0.05)$ in $\mathrm{R}$. Linear regressions comparing foliar $\mathrm{N}$ content with dollar spot severity and comparing $\mathrm{N}$ application rate with foliar N content were calculated in PROC Reg in SAS (SAS version 9.3, Cary, NC). For data from 2016 and 2017, a second regression analysis was conducted in which mixed-model linear regression was compared with nonlinear mixed-model regression to describe the relationship of $\mathrm{N}$ application rate to standardized AUDPC. Data from 2015 were not included in this analysis because of a dollar outbreak that occurred in late May, before treatments could be initiated. The GLIMMIX procedure of SAS (version 9.4, Cary, NC) was used to generate a linear regression solution in which $\mathrm{N}$ rate was a fixed effect explaining standardized AUDPC and site-year (year by location) as a random effect. PROC NLMIXED was used in SAS to fit a logistic growth curve model as described by Littell et al. (2006) and briefly outlined in Equation 1:

$$
Y_{i j}=\frac{\beta_{1}+\mu_{i 1}}{1+\left(\beta_{2}+\mu_{i 2}\right) \exp \left\{-x_{i j} / \beta_{3}\right\}}+e_{i j}
$$

where $\beta_{1}$ is the upper asymptote of the sigmoidal curve, $\beta_{2}$ is the shape parameter of the curve, and $\beta_{3}$ is the rate scale parameter. In addition, two random effect parameters, $\mu_{1}$ and $\mu_{2}$, were included to allow each experimental unit to have its own subject-specific $\beta_{1}$ and $\beta_{2}$ parameters. The residual errors $e_{i j}$ are assumed to be independent and identically distributed random variables with mean zero and variance $\sigma^{2}$. Best fit between models was determined by convergence of the model and appropriate fit statistics. Starting parameter estimates were as follows in the NLMIXED procedure: $\beta_{1}=120$, $\beta_{2}=25, \beta_{3}=-10, \mu_{1}=500$, and $\mu_{2}=150$. Turfgrass quality results were analyzed via the Kruskal-Wallis test in the kruskal function of the agricolae package in R. Linear regression graphs and box plots were made with the ggplot 2 package in $\mathrm{R}$, and the disease progress curves and nonlinear regression graph were made in Plotly Chart Studio (https://chart-studio.plotly.com/feed/\#/).

\section{Results}

Nitrogen rate study. Dollar spot symptoms at both OJN and NSCC developed slowly but steadily in 2016 and 2017. In 2015, however, a severe dollar spot outbreak occurred at OJN in May before treatments were initiated but then dissipated to almost no disease in midsummer after an extended period of cool and dry conditions (Fig. 1). In addition, dollar spot treatment responses were highly variable at both locations in 2015 before becoming more consistent in 2016 and 2017. In all years and at both sites, the most effective and consistent suppression of dollar spot occurred at $29.3 \mathrm{~kg} \mathrm{~N} / \mathrm{ha}$, and almost no dollar spot suppression was observed at 4.9 and $9.8 \mathrm{~kg} \mathrm{~N} /$ ha relative to the nonfertilized control (Supplementary Table S1). A pairwise comparison of average annual foci development on each treatment over all six site-years found that dollar spot was always more severe at $0.0,4.9,9.8$, and $19.4 \mathrm{~kg} \mathrm{~N} / \mathrm{ha}$ relative to $29.3 \mathrm{~kg} \mathrm{~N} / \mathrm{ha}$ (Table 2). However, dollar spot severities between $0.0,4.9$, and $9.8 \mathrm{~kg} \mathrm{~N} / \mathrm{ha}$ were different from each other only one time, at NSCC in 2015. The $29.3 \mathrm{~kg} \mathrm{~N} /$ ha treatment even provided dollar spot control comparable to the fungicide program in all three years at OJN and in 2017 at NSCC. A regression analysis of the N rate treatments versus the standardized AUDPC values from 2016 and 2017 at both locations indicated that the logistic growth curve model provided the best fit, with a substantial reduction in disease at the $29.3 \mathrm{~kg} \mathrm{~N} / \mathrm{ha}$ level (Fig. 2).

Turfgrass quality mostly reflected the dollar spot severity results, and the $29.3 \mathrm{~kg} \mathrm{~N} / \mathrm{ha}$ treatment and the fungicide program had the highest quality in most site-years (Fig. 3). However, turf quality of the fungicide program at OJN decreased in 2016 and 2017 relative to the $29.3 \mathrm{~kg} \mathrm{~N} / \mathrm{ha}$ treatment because of decreasing density and color in the absence of any fertilizer for such a long period. This decrease in fungicide program turf quality in 2016 and 2017 was not observed at NSCC. Turfgrass color as represented by NDVI exhibited a dosedependent increase with increasing $\mathrm{N}$ rates and also was similar to both the disease and turf quality results (Fig. 3).

Tissue $\mathrm{N}$ content increased with increasing $\mathrm{N}$ application rate (Fig. $4 ; P<0.001$ ), and when averaged across all 3 years and both locations $\mathrm{N}$ content was generally between 2.5 and $4 \%$ (data not shown). Dollar spot foci decreased in response to increasing foliar $\mathrm{N}$ content from both sites in 2016 and 2017 (Fig. 5; $P<0.001$ ). The $29.3 \mathrm{~kg} \mathrm{~N} /$ ha treatment in September 2017 was the only treatment to exhibit a significant $(P=0.049)$ negative linear relationship between dollar spot infection centers and tissue $\mathrm{N}$ content (Fig. 6).

Nitrogen source study. Nitrogen source impacts on dollar spot severity were apparent relative to the nonfertilized control but generally
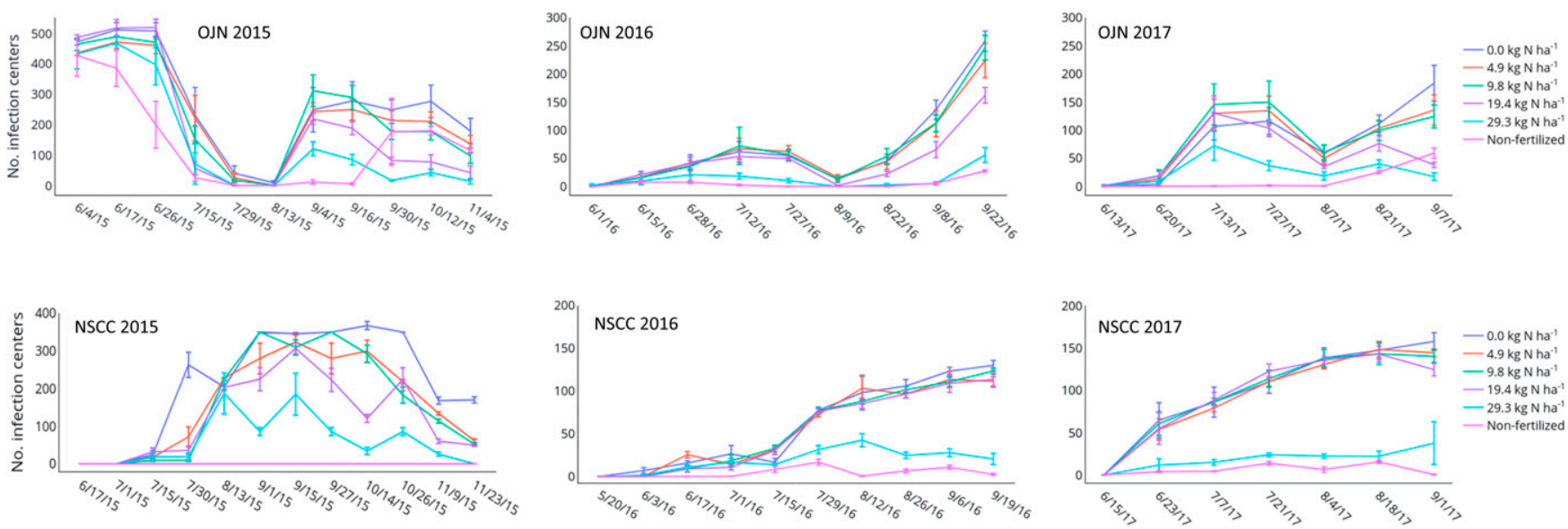

Fig. 1. Dollar spot disease progress curve represented as average number of infection centers over 4 replicates in 2015, 2016, and 2017 at the North Shore Country Club (NSCC) and O.J. Noer Turfgrass Research Facility (OJN). Error bars represent the standard error of the mean. 
minimal when compared with each other (Fig. 7, Table 3). Calcium nitrate reduced dollar spot relative to the nonfertilized control in 4 of 6 site-years and reduced dollar spot relative to at least one other $\mathrm{N}$ source in 2 site-years (Table 3). Though not significant at every site-year, AUDPC was always lowest in the calcium nitrate treatment relative to the other $\mathrm{N}$ source treatments.

Nitrogen source did not generally affect turfgrass quality because no source provided effective dollar spot suppression (Fig. 8). Turf quality was usually lowest in the nonfertilized control and highest in the fungicide program, although turf quality in the fungicide program treatment did begin to decline at OJN by 2017 after 3 years of no fertilizer inputs. Turf color as represented by NDVI rarely responded to $\mathrm{N}$ source and by the 2017 was lowest in the nonfertilized control and the nonfertilized fungicide program (Fig. 8).

Nitrogen source affected foliar $\mathrm{pH}$ at both locations in both 2016 and 2017, although differences between treatments were generally less than a tenth of a unit (Table 4). Foliar $\mathrm{pH}$ values ranged between 6.2 and 6.5 at both locations in both years, and calcium nitrate treatments nearly always had the highest foliar $\mathrm{pH}$ whereas ammonium sulfate treatments always had the lowest. Nitrogen source rarely affected soil pH, the only exception being OJN in 2016 (Table 4). Soil $\mathrm{pH}$ generally ranged between 7 and 7.4, and though rarely significant, calcium nitrate treatments generally had the highest soil $\mathrm{pH}$ and ammonium sulfate generally the lowest.

\section{Discussion}

The research presented here clearly demonstrates that the $29.3 \mathrm{~kg}$ $\mathrm{N} /$ ha rate of foliar $\mathrm{N}$ applied to a golf course putting green on a 14day interval significantly reduced dollar spot relative to all lower $\mathrm{N}$ rates. This non-dose-dependent response was apparent at both OJN and NSCC and is supported by both the nonlinear regression analysis (Fig. 2) and the pairwise comparison results (Table 2). These results did not support our hypothesis, which expected a dosedependent decrease in dollar spot with increasing $\mathrm{N}$ rate, and it somewhat contradicts earlier research on the subject. Golembiewski and Danneberger (1998), Markland et al. (1969), and Williams et al. (1996) all found decreasing dollar spot severity with increasing $\mathrm{N}$ rates, but in each of these studies the fertilizer was applied as a granular application. One potential explanation for the differences in dollar spot suppression tested in our research and the granular programs described previously is the number of treatments analyzed. Our study tested five $\mathrm{N}$ rates, whereas the aforementioned studies all tested three $\mathrm{N}$ rates, and establishing a dose-response relationship by using only three data points is less rigorous than using five data points. In addition, the aforementioned studies applied the fertilizers one to five times per year, whereas ours applied each product 10 times per year, which may have affected $\mathrm{N}$ uptake efficiency and consistency of plant growth.

Previous researchers have tested the impact of foliar-applied $\mathrm{N}$ on dollar spot severity. Landschoot and McNitt (1997) tested the impacts of four annual applications of foliar-applied urea at rates of 24 and $48 \mathrm{~kg} \mathrm{~N} / \mathrm{ha}$ and found that dollar spot was slightly reduced in the $48 \mathrm{~kg} \mathrm{~N} / \mathrm{ha}$ treatment relative to the nonfertilized control but not the $24 \mathrm{~kg} \mathrm{~N} / \mathrm{ha}$ treatment. Given the total amount of $\mathrm{N}$ applied between the Landschoot and McNitt (1997) study (96 and $192 \mathrm{~kg}$ $\mathrm{N} / \mathrm{ha}$ annually) and our study $(0.0,49,98,194$, and $293 \mathrm{~kg} \mathrm{~N} / \mathrm{ha})$, the level of dollar spot control achieved at the various $\mathrm{N}$ rates appears quite comparable. Ryan et al. (2011) used a similar spoonfeeding fertilization approach as our study to evaluate foliar-applied urea at the rate of $7.3 \mathrm{~kg} \mathrm{~N} / \mathrm{ha}$ on dollar spot severity and found a minor dollar spot reduction in 1 of 2 years. Our results never showed a reduction in dollar spot at an N level this low, but Ryan et al. (2011) did not test multiple $\mathrm{N}$ rates, so it is difficult to know whether a doseresponse effect would have been observed. Rather than our results contradicting earlier results, it appears that the earlier evidence for dose-dependent reductions in dollar spot were based on two to five applications of granular fertilizer and not based on spoonfed,

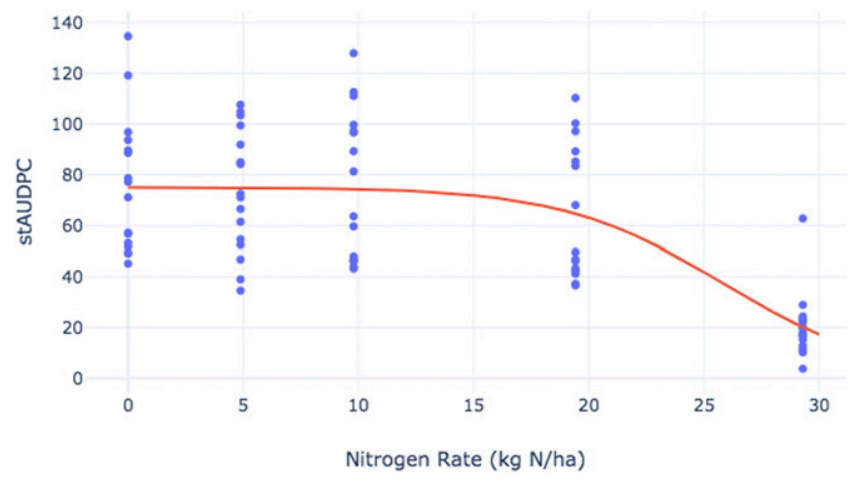

Fig. 2. Dollar spot severity as expressed by standardized area under the disease progress curve (stAUDPC) in response to nitrogen application rate $(0.0,4.88,9.79$, 19.42, and $29.29 \mathrm{~kg} \mathrm{~N} / \mathrm{ha}$ ) in 2016 and 2017 at the O.J. Noer Turfgrass Research Facility in Madison, Wisconsin and North Shore Country Club in Glenview, Illinois. The red trendline shows the logistic growth curve model fit to these via using a nonlinear, mixed model approach where nitrogen application rate was a fixed effect to describe stAUDPC and site-year was considered a random effect. The following parameters were estimated during the model fitting exercise: $\beta_{1}=75.1, \beta_{2}=25.8$, $\beta_{3}=-3.5$.

Table 2. Differences in average annual dollar spot foci between nitrogen treatments at North Shore Country Club (NSCC) in Glenview, Illinois and the O.J. Noer Turfgrass Research Facility (OJN) in Madison, Wisconsin in 2015, 2016, and 2017

\begin{tabular}{|c|c|c|c|c|c|c|c|}
\hline \multirow[b]{2}{*}{ Treatment comparison } & \multicolumn{3}{|c|}{ OJN } & \multicolumn{3}{|c|}{ NSCC } & \multirow[b]{2}{*}{ No. times different } \\
\hline & 2015 & 2016 & 2017 & 2015 & 2016 & 2017 & \\
\hline 0.0 versus 4.88 & $\mathrm{NS}^{\mathrm{y}}$ & NS & NS & $* \mathrm{z}$ & NS & NS & 1 \\
\hline 0.0 versus 9.79 & NS & NS & NS & $*$ & NS & NS & 1 \\
\hline 0.0 versus 19.42 & $*$ & $*$ & NS & $*$ & $*$ & NS & 3 \\
\hline 0.0 versus 29.29 & $*$ & $*$ & $*$ & $*$ & $*$ & $*$ & 6 \\
\hline 0.0 versus Fung & * & $*$ & $*$ & $*$ & $*$ & * & 6 \\
\hline 4.88 versus 9.79 & NS & NS & NS & NS & NS & NS & 0 \\
\hline 4.88 versus 19.42 & $*$ & $*$ & NS & $*$ & NS & NS & 3 \\
\hline 4.88 versus 29.29 & $*$ & $*$ & $*$ & $*$ & $*$ & $*$ & 6 \\
\hline 4.88 versus Fung & $*$ & $*$ & $*$ & $*$ & $*$ & $*$ & 6 \\
\hline 9.79 versus 19.42 & NS & $*$ & NS & $*$ & NS & NS & 2 \\
\hline 9.79 versus 29.29 & $*$ & $*$ & $*$ & $*$ & $*$ & $*$ & 6 \\
\hline 9.79 versus Fung & $*$ & $*$ & $*$ & $*$ & $*$ & $*$ & 6 \\
\hline 19.42 versus 29.29 & $*$ & $*$ & $*$ & $*$ & $*$ & $*$ & 6 \\
\hline 19.42 versus Fung & $*$ & $*$ & $*$ & $*$ & $*$ & $*$ & 6 \\
\hline 29.29 versus Fung & NS & NS & NS & $*$ & $*$ & NS & 2 \\
\hline
\end{tabular}

${ }^{\mathrm{y}} \mathrm{NS}$ indicates no difference between treatments within each location and year.

${ }^{\mathrm{z}}$ Asterisk indicates statistical difference at the $P=0.05$ level. 
foliar-applied $\mathrm{N}$ programs that are widely used by many golf course superintendents (Beard 1973; Latin 2011; Smiley et al. 2005).

The mechanism for the sharp dollar spot decline at the $29.3 \mathrm{~kg}$ $\mathrm{N} /$ ha rate remains unclear. Landschoot and McNitt (1997) and others have argued that higher $\mathrm{N}$ rates increase plant growth and allow "escape" from the pathogen. However, plant growth rate should increase in a dose-dependent manner in response to increasing $\mathrm{N}$ fertilization, which should lead to a dose-dependent reduction in dollar spot if "escape" were a primary mechanism. We did not assess plant growth rate through techniques such as measuring clipping yield, and future research assessing dollar spot development as a function of plant growth is warranted to provide more information on this topic. Previous research has shown that induced and constitutive disease resistance marker expression can be increased when exposed to higher $\mathrm{N}$ application rates (Dietrich et al. 2004; Huber and Thompson 2007). A dose-dependent decrease in dollar spot would also be expected if this were the primary response to increasing $\mathrm{N}$, although no expression of resistance genes was conducted as part of this study, so it cannot be dismissed.

Higher $\mathrm{N}$ rates may also alter the structure and function of the microbial community to be more antagonistic to the dollar spot pathogen. Nelson and Craft (1991) demonstrated significant reductions in dollar spot after topdressing golf course turfgrass with Enterobacter-infested cornmeal. Nelson and Craft (1992) also observed less dollar spot after topdressing applications of various organic composts, and because $\mathrm{N}$ was not deficient in these plants, the authors suggested that altered microflora were contributing to the lower dollar spot. Liu et al. (1995) observed less dollar spot after applications of several organic and inorganic fertilizers to turfgrass and found higher bacterial counts on the leaves and in the soil of several organic and inorganic fertilizer treatments. Beirn (2016) found that the microbial communities of

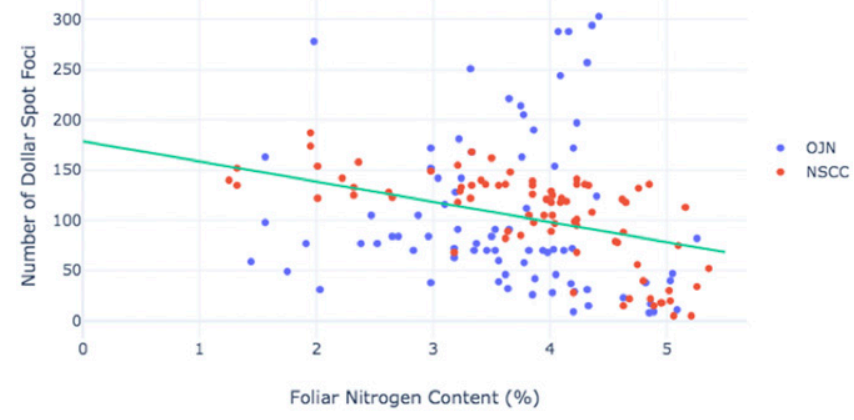

Fig. 5. Dollar spot infection centers in response to foliar $\mathrm{N}$ content from North Shore Country Club (NSCC) and O.J. Noer Turfgrass Research Facility (OJN) in August and September 2016 and 2017. The green trendline shows a linear regression with a $P$ of 0.0001 , slope of $-20.08, y$-intercept of 178.76 , and adjusted $R^{2}$ value of 0.08 .
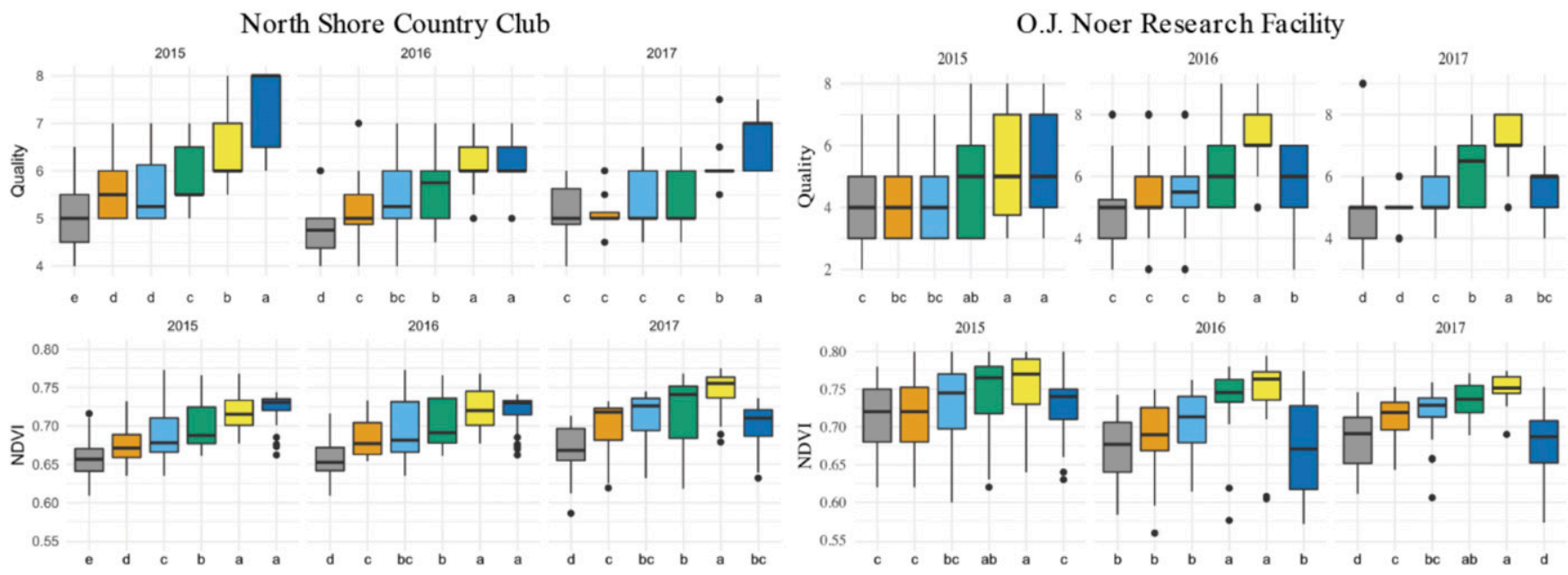

追 Non-Treated 追 $4.88 \mathrm{~kg} \mathrm{~N}$ 官 $9.79 \mathrm{~kg} \mathrm{~N}$ 审 $19.42 \mathrm{~kg} \mathrm{~N}$ 官 $29.29 \mathrm{~kg} \mathrm{~N}$ Fungicide Program

Fig. 3. Turfgrass quality and normalized differential vegetative index (NDVI) from 2015, 2016, and 2017 at the North Shore Country Club and O.J. Noer Turfgrass Research Facility. Box plot whiskers represent $\pm 1.5 \times$ interquartile range. Statistics for each site-year were calculated independently, and differences between each treatment are denoted by the letters at the bottom of each graph according to Fisher's least significant difference $(P>0.05)$.
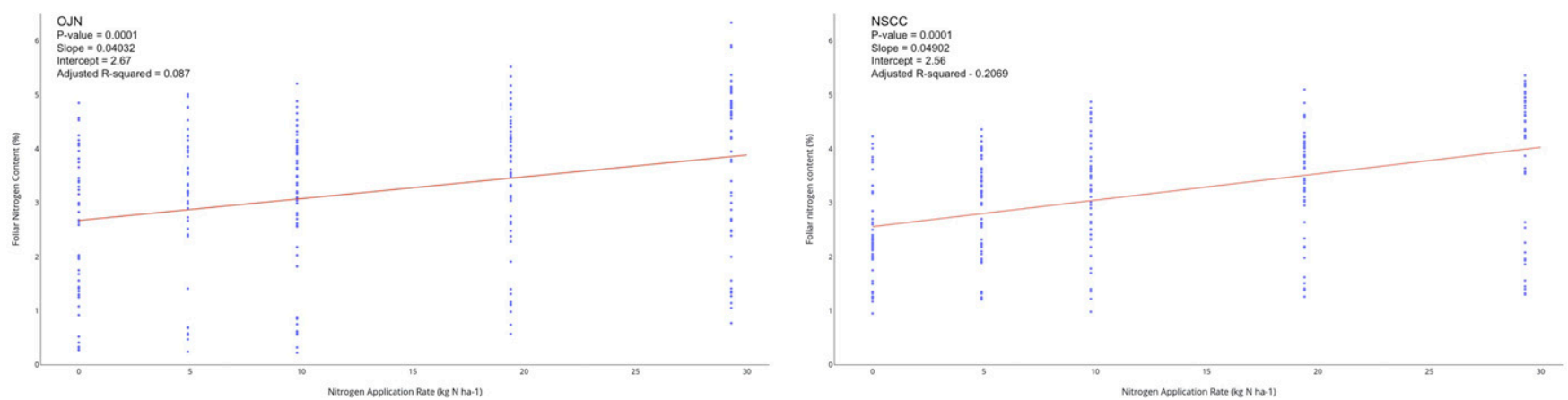

Fig. 4. Foliar nitrogen content in response to nitrogen application rate $(0.0,4.88,9.79,19.42$, and $29.29 \mathrm{~kg} \mathrm{~N} / \mathrm{ha})$ in 2015, 2016, and 2017 at the $0 . \mathrm{J}$. Noer Turfgrass Research Facility (OJN) in Madison, Wisconsin and North Shore Country Club (NSCC) in Glenview, Illinois. There were 260 total observations at each location, and the red trendline shows the linear regression for each location. 
annual bluegrass putting greens in New Jersey shifted in response to applications of urea and potassium fertilizers, although disease assessments were not conducted as part of this research. In our own work we also sampled the soil microbial community in the final year of the study and found that soil bacterial communities in the $29.3 \mathrm{~kg} \mathrm{~N} / \mathrm{ha}$ treatment were distinct from those of the other $\mathrm{N}$ rate treatments (M. Millican, unpublished data). These data are being analyzed and prepared for inclusion in a separate peer-reviewed manuscript. The previous research outlined earlier and the nonlinear dollar spot response to $\mathrm{N}$ observed in this research suggest that microbial activity plays a critical role in suppressing dollar spot at high $\mathrm{N}$ fertilization rates.

Previous research has suggested that a foliar $\mathrm{N}$ content $>5 \%$ results in less dollar spot on creeping bentgrass (Garling 2000). Our research also suggests that foliar $\mathrm{N}$ content affects dollar spot severity, although the approximate cutoff in our research was $4.5 \%$ foliar $\mathrm{N}$. The $29.3 \mathrm{~kg} \mathrm{~N} / \mathrm{ha}$ treatment provided the greatest number of samples with a foliar $\mathrm{N}$ content $>4.5 \%$, which probably contributed to its efficacy against dollar spot. Future research should focus on foliar $\mathrm{N}$ content as opposed to $\mathrm{N}$ application rates and also test methods to increase foliar $\mathrm{N}$ content without applying such high $\mathrm{N}$ rates, perhaps by combining $\mathrm{N}$ applications with plant growth regulators.

Synthetic N sources selected based on their ability to manipulate foliar or soil $\mathrm{pH}$ had minimal impacts on dollar spot severity, foliar $\mathrm{pH}$, and soil $\mathrm{pH}$. Source impacts on dollar spot were more commonly observed at NSCC than at OJN, and in every case, whether the differences were significant or not, dollar spot was lowest in the calcium nitrate treatments relative to ammonium nitrate and ammonium sulfate. Even when significant differences were apparent, however, their practical relevance is questionable because dollar spot severity remained high in response to each $\mathrm{N}$ source. Foliar $\mathrm{pH}$ was also highest in the calcium nitrate treatments in five of six site-years, although this was expected based on the alkaline properties of calcium nitrate. One potentially mitigating factor in this study was the $\mathrm{pH}$ of the irrigation water at both OJN and NSCC, which ranged from 7.8 to 8.5. The alkaline water may have affected the $\mathrm{pH}$ effect of the individual treatments and altered any potential impact on dollar spot development. In addition, soil tests were not conducted before the initiation of the trial at either location so particular deficiencies in soil calcium or other soil factors that may have been addressed by these treatments

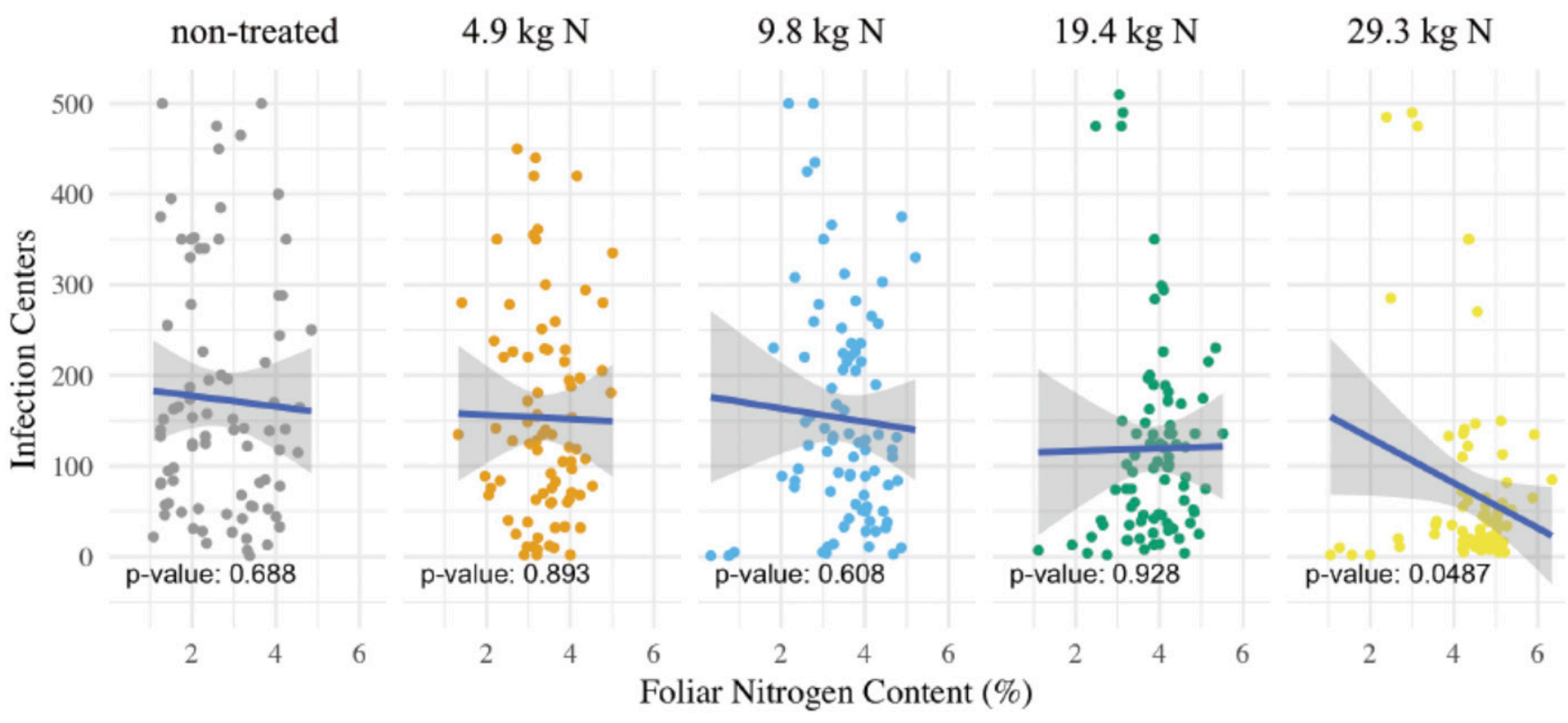

Fig. 6. Dollar spot infection centers in response to foliar N content from North Shore Country Club (NSCC) and O.J. Noer Turfgrass Research Facility (OJN) in September 2017 after $\mathrm{N}$ application rates of $0.0,4.88,9.79,19.42$, and $29.29 \mathrm{~kg} \mathrm{~N} / \mathrm{ha}$. Statistical significance was determined with an analysis of variance $(P<0.05)$.
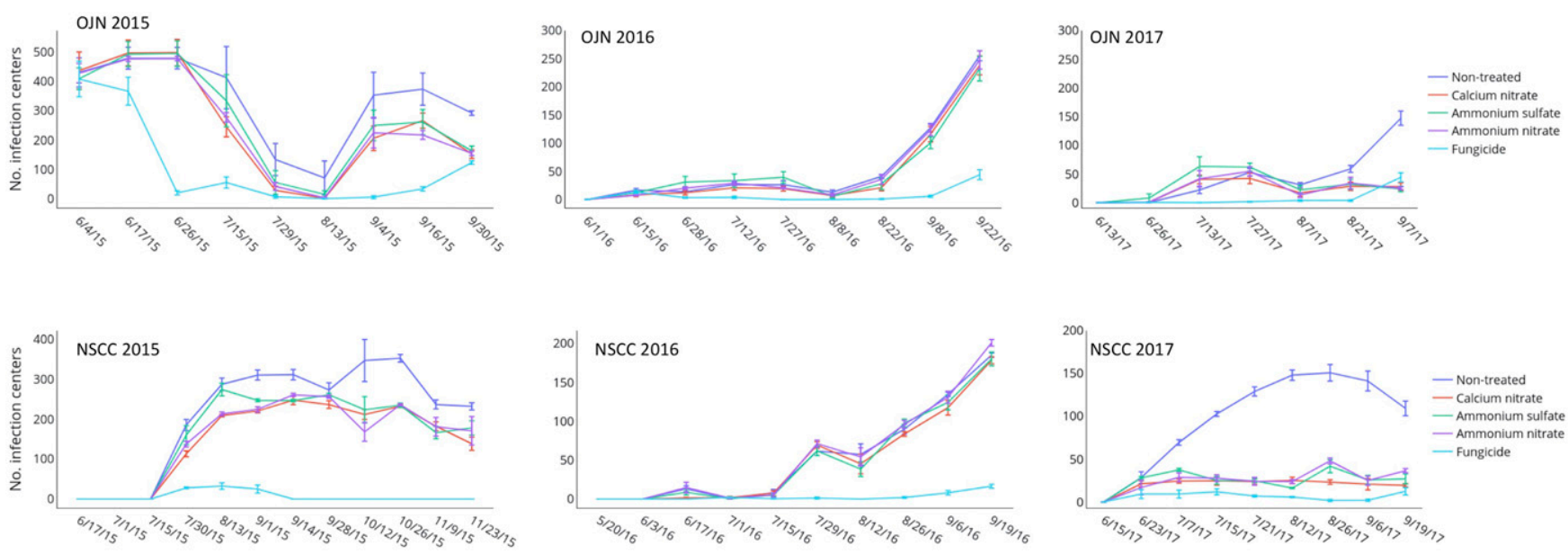

Fig. 7. Dollar spot disease progress curve represented as average number of infection centers in 2015, 2016, and 2017 at North Shore Country Club (NSCC) and O.J. Noer Turfgrass Research Facility (OJN). Error bars represent the standard error of the mean. 
is unknown. However, this research supports previous research that $\mathrm{N}$ source as it relates to $\mathrm{pH}$ has a minimal impact on dollar spot severity (Davis and Dernoeden 2002; Smiley et al. 2005).

The fungicide program tested in the $\mathrm{N}$ rate trial consistently provided the most effective dollar spot suppression over the full season, though at significant financial cost. In August 2018 the cost of urea was approximately 50 cents $/ \mathrm{kg}$ from a local supplier in Madison, Wisconsin. At this price, the total cost of $\mathrm{N}$ applications at $29.3 \mathrm{~kg}$ $\mathrm{N} /$ ha made 10 times per year would be $150 \mathrm{USD} / \mathrm{ha}$. We estimated the fungicide program used in our study to cost approximately 400 USD/ha based on pricing provided by local distributors, and because the average golf course has approximately 12.1 ha of fairways, the savings of using only fertilizer as opposed to fungicides can exceed \$3,000 annually (Golf Course Superintendents Association of America 2007). Relying solely on $\mathrm{N}$ to suppress dollar spot did not provide complete disease control in our work, but a combination of increasing $\mathrm{N}$ while reserving fungicide usage for times of highest

Table 3. Dollar spot severity as represented by the area under the disease progress curve (AUDPC) at North Shore Country Club (NSCC) in Glenview, Illinois and the O.J. Noer Turfgrass Research Facility (OJN) Madison, Wisconsin in 2015, 2016 and 2017

\begin{tabular}{lrrrrrr}
\hline & \multicolumn{2}{c}{ OJN } & & \multicolumn{2}{c}{ NSCC } & \\
\cline { 2 - 3 } \cline { 5 - 6 } Treatment & AUDPC & SE & & AUDPC & SE & \\
\hline Nonfertilized & $325.92^{\mathrm{z}}$ & $16.24 \mathrm{a}$ & & 137.55 & $3.07 \mathrm{a}$ & 2015 \\
Calcium nitrate & 230.55 & $16.24 \mathrm{~b}$ & & 98.23 & $3.07 \mathrm{c}$ & \\
Ammonium sulfate & 250.82 & $16.24 \mathrm{~b}$ & & 113.94 & $3.07 \mathrm{~b}$ & \\
Ammonium nitrate & 231.26 & $16.24 \mathrm{~b}$ & & 106.28 & $3.07 \mathrm{bc}$ & \\
Fungicide program & 103.23 & $16.24 \mathrm{c}$ & 8.44 & $3.07 \mathrm{~d}$ & \\
Nonfertilized & 50.57 & $3.95 \mathrm{a}$ & & 42.26 & $1.48 \mathrm{ab}$ & 2016 \\
Calcium nitrate & 41.80 & $3.95 \mathrm{a}$ & & 38.41 & $1.48 \mathrm{~b}$ & \\
Ammonium sulfate & 46.99 & $3.95 \mathrm{a}$ & & 39.25 & $1.48 \mathrm{~b}$ & \\
Ammonium nitrate & 47.59 & $3.95 \mathrm{a}$ & & 43.81 & $1.48 \mathrm{a}$ & \\
Fungicide program & 6.16 & $3.95 \mathrm{~b}$ & & 2.03 & $1.48 \mathrm{c}$ & \\
Nonfertilized & 39.97 & $5.17 \mathrm{a}$ & & 105.04 & $2.25 \mathrm{a}$ & 2017 \\
Calcium nitrate & 24.07 & $5.17 \mathrm{a}$ & & 21.98 & $2.25 \mathrm{~b}$ & \\
Ammonium sulfate & 33.31 & $5.17 \mathrm{a}$ & & 25.91 & $2.25 \mathrm{~b}$ & \\
Ammonium nitrate & 26.30 & $5.17 \mathrm{a}$ & & 25.91 & $2.25 \mathrm{~b}$ & \\
Fungicide program & 7.42 & $5.17 \mathrm{~b}$ & 6.14 & $2.25 \mathrm{c}$ & \\
\hline z & & &
\end{tabular}

${ }^{\mathrm{z}}$ Statistics for each site-year were calculated independently, and values followed by the same letter are not significantly different according to Fisher's least significant difference $(P>0.05)$. disease pressure may provide financial savings and effective dollar spot control relative to a traditional fungicide program.

Dollar spot reductions and financial savings relative to fungicide programs can be achieved by increasing $\mathrm{N}$ rates, but increasing $\mathrm{N}$ rates can result in several negative outcomes. Although individual applications of $29.3 \mathrm{~kg} / \mathrm{ha}$ are not likely to pose significant environmental risks (Petrovic 1990), the cumulative effects of the repeated applications are likely to eventually lead to an environmentally significant level of $\mathrm{N}$ leaching (Frank et al. 2006). In addition, high $\mathrm{N}$ applications will increase the rate of soil organic matter and soil

Table 4. Soil and foliar $\mathrm{pH}$ as affected by nitrogen source at North Shore Country Club (NSCC) in Glenview, Illinois and the O.J. Noer Turfgrass Research Facility (OJN) in Madison, Wisconsin in 2016 and 2017

\begin{tabular}{|c|c|c|c|c|c|}
\hline \multirow[b]{2}{*}{ Treatment } & \multicolumn{2}{|c|}{ OJN } & \multicolumn{2}{|c|}{ NSCC } & \\
\hline & Foliar pH & SE & Foliar pH & SE & \\
\hline Nonfertilized & $6.41^{z}$ & $0.04 \mathrm{ab}$ & 6.25 & $0.01 \mathrm{~b}$ & 2016 \\
\hline Calcium nitrate & 6.44 & $0.04 \mathrm{ab}$ & 6.28 & $0.01 \mathrm{a}$ & \\
\hline Ammonium sulfate & 6.36 & $0.04 \mathrm{~b}$ & 6.20 & $0.01 \mathrm{c}$ & \\
\hline Ammonium nitrate & 6.39 & $0.04 \mathrm{ab}$ & 6.24 & $0.01 \mathrm{~b}$ & \\
\hline Fungicide program & 6.47 & $0.04 \mathrm{a}$ & 6.22 & $0.01 \mathrm{bc}$ & \\
\hline Nonfertilized & 6.29 & $0.01 \mathrm{ab}$ & 6.27 & $0.01 \mathrm{ab}$ & 2017 \\
\hline Calcium nitrate & 6.30 & $0.01 \mathrm{a}$ & 6.30 & $0.01 \mathrm{a}$ & \\
\hline Ammonium sulfate & 6.25 & $0.01 \mathrm{c}$ & 6.23 & $0.01 \mathrm{c}$ & \\
\hline Ammonium nitrate & 6.29 & $0.01 \mathrm{ab}$ & 6.27 & $0.01 \mathrm{ab}$ & \\
\hline \multirow[t]{2}{*}{ Fungicide program } & 6.26 & $0.01 \mathrm{bc}$ & 6.26 & $0.01 \mathrm{bc}$ & \\
\hline & Soil pH & SE & Soil pH & SE & \\
\hline Nonfertilized & 7.12 & $0.05 \mathrm{ab}$ & 7.23 & $0.07 \mathrm{a}$ & \\
\hline Calcium nitrate & 7.27 & $0.05 \mathrm{a}$ & 7.27 & $0.07 \mathrm{a}$ & \\
\hline Ammonium sulfate & 6.99 & $0.05 \mathrm{c}$ & 7.13 & $0.07 \mathrm{a}$ & \\
\hline Ammonium nitrate & 7.10 & $0.05 \mathrm{bc}$ & 7.24 & $0.07 \mathrm{a}$ & \\
\hline Fungicide program & 7.17 & $0.05 a b$ & 7.32 & $0.07 \mathrm{a}$ & 2016 \\
\hline Nonfertilized & 7.40 & $0.02 \mathrm{a}$ & 7.32 & $0.03 \mathrm{a}$ & \\
\hline Calcium nitrate & 7.36 & $0.02 \mathrm{a}$ & 7.38 & $0.03 \mathrm{a}$ & \\
\hline Ammonium sulfate & 7.34 & $0.02 \mathrm{a}$ & 7.32 & $0.03 \mathrm{a}$ & \\
\hline Ammonium nitrate & 7.36 & $0.02 \mathrm{a}$ & 7.34 & $0.03 \mathrm{a}$ & \\
\hline Fungicide program & 7.39 & $0.02 \mathrm{a}$ & 7.36 & $0.03 \mathrm{a}$ & 2017 \\
\hline
\end{tabular}

${ }^{\mathrm{z}}$ Statistics for each site-year were calculated independently, and values followed by the same letter are not significantly different according to Fisher's least significant difference $(P>0.05)$.

\section{North Shore Country Club}
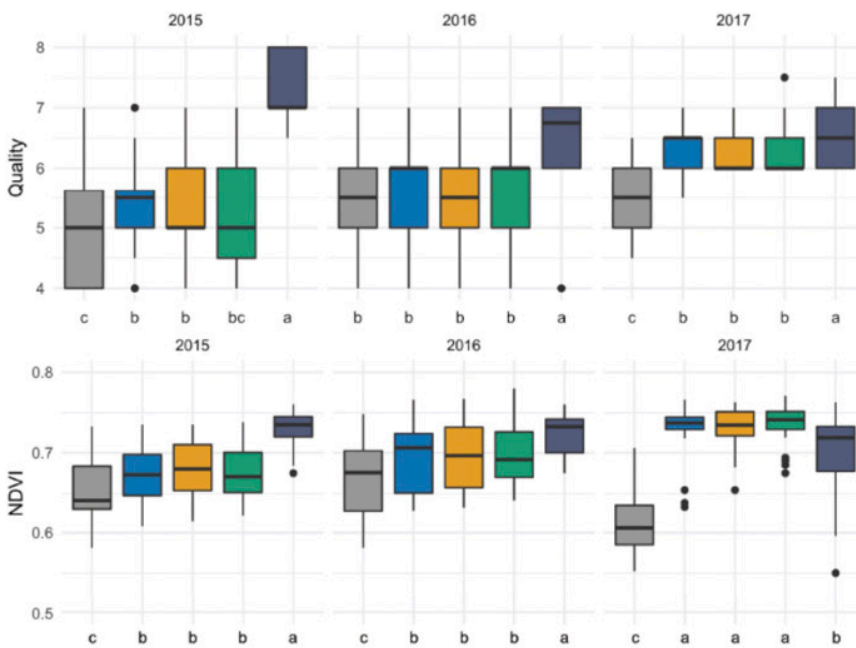

O.J. Noer Research Facility
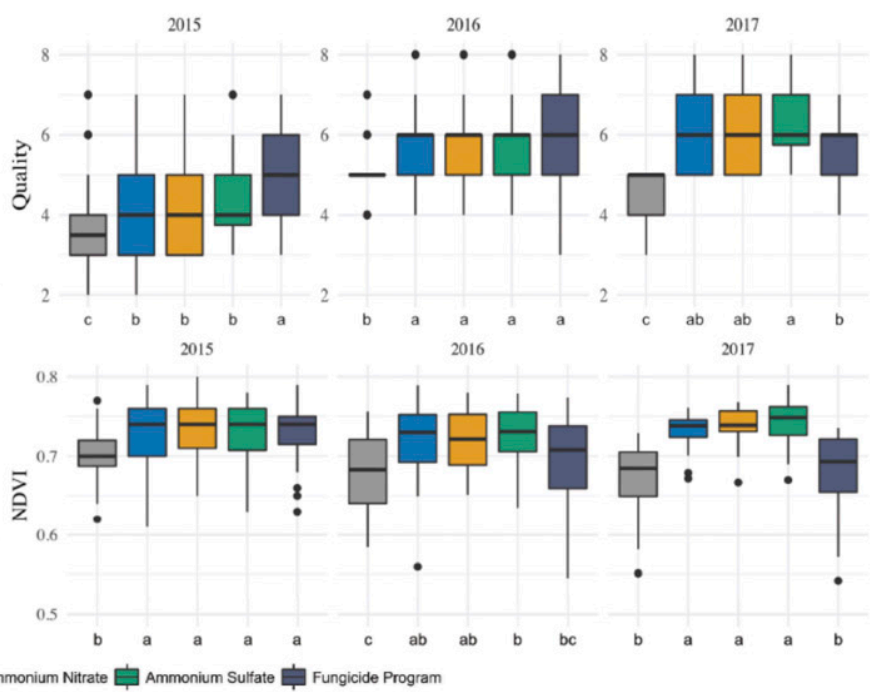

Fig. 8. Turfgrass quality scores and normalized differential vegetative index (NDVI) from North Shore Country Club (NSCC) and O.J. Noer Turfgrass Research Facility (OJN) in 2015, 2016, and 2017. Box plot whiskers represent $\pm 1.5 \times$ interquartile range. Statistics for each site-year were calculated independently, and differences between each treatment are denoted by the letters at the bottom of each graph according to Fisher's least significant difference $(P>0.05)$. 
organic $\mathrm{N}$ accumulation that will need to be managed through costly cultivation techniques such as aeration and topdressing (Golembiewski and Danneberger 1998; Soper et al. 1988). Lastly, higher N promotes destructive turfgrass diseases such as brown patch (Rhizoctonia solani) and Pythium blight (Pythium aphanidermatum) (Burpee 1995; Freeman 1974). Although brown patch and Pythium blight are less common than dollar spot, any increase in fungicide usage to suppress these other diseases will negate the benefits achieved through less fungicide usage targeting dollar spot.

As mentioned previously, one method to potentially increase foliar $\mathrm{N}$ content without increasing clipping yield is to incorporate plant growth regulators. Plant growth regulators are regularly used by golf course superintendents to manage plant growth for a variety of reasons such as improved playability, plant health, and annual bluegrass seedhead suppression (Kreuser and Soldat 2011). In particular, a growing degree-day model for use in timing plant growth regulator applications was reported by Kreuser and Soldat (2011) and may aid golf course superintendents in managing excess clipping production without sacrificing foliar $\mathrm{N}$ content. Future research investigating whether plant growth regulators may help increase foliar $\mathrm{N}$ content and reduce dollar spot while mitigating the negative side effects of high $\mathrm{N}$ application is warranted.

Increasing $\mathrm{N}$ on golf course turfgrass can dramatically decrease dollar spot severity in creeping bentgrass. Numerous fungicides are available to golf course superintendents in the United States for effective dollar spot control, and the dollar spot-suppressing benefits of higher $\mathrm{N}$ may not outweigh the negative environmental and management aspects. However, fungicides are severely restricted in many other temperate climates around the world, and higher $\mathrm{N}$ rates may provide an effective and financially feasible method of dollar spot suppression for these locations if future chemical restrictions are implemented in the United States. Regardless, $\mathrm{N}$ plays an important role in dollar spot management and should be considered as part of integrated pest management for suppressing dollar spot with fewer pesticides and lower cost.

\section{Acknowledgments}

The authors thank Dan Dinelli, superintendent at North Shore Country Club in Glenview, Illinois for hosting the research trials at his golf course. At the time this work was completed, R. V. Townsend was with the University of Wisconsin-Madison. He is now employed by SePRO Corporation, Carmel, Indiana.

\section{Literature Cited}

Beard, J. B. 1973. Turfgrass: Science and Culture. Prentice-Hall, Inc, Englewood Cliffs, NJ.

Beirn, L. A. 2016. Molecular insights into the microbial community of annual bluegrass (Poa annua L.) putting green turf.PhD dissertation, Rutgers University, New Brunswick, NJ.

Burpee, L. L. 1995. Interactions among mowing height, $\mathrm{N}$ fertility, and cultivar affect the severity of rhizoctonia blight of tall fescue. Plant Dis. 79:721-726.

Burpee, L. L. 1997. Control of dollar spot of creeping bentgrass caused by an isolate of Sclerotinia homoeocarpa resistant to benzimidazole and demethylation-inhibitor fungicides. Plant Dis. 81:1259-1263.

Campbell, C. L., and Madden, L. V. 1990. Introduction to Plant Disease Epidemiology. Wiley, New York, NY.

Carrow, R. N., Waddington, D. V., and Rieke, P. E. 2007. Turfgrass Soil Fertility and Chemical Problems: Assessment and Management. Ann Arbor Press, Chelsea, MI.

Cornelissen, J. H. C., Quested, H. M., Logtestijn, R. S. P., Pérez-Harguindeguy, N., Gwynn-Jones, D., Díaz, S., Callaghan, T. V., Press, M. C., and Aerts, R. 2006. Foliar $\mathrm{pH}$ as a new plant trait: can it explain variation in foliar chemistry and carbon cycling processes among subarctic plant species and types? Oecologia 147:315-326.

Davis, J., and Dernoeden, P. 2002. Dollar spot severity, tissue nitrogen, and soil microbial activity in bentgrass as influenced by nitrogen source. Crop Sci. 42:480-488.

Dernoeden, P. H. 2002. Creeping Bentgrass Management: Summer Stresses, Weeds and Selected Maladies. John Wiley \& Sons, Hoboken, NJ.

Detweiler, A., Vargas, J., and Danneberger, T. 1983. Resistance of Sclerotinia homoeocarpa to iprodione and benomyl. Plant Dis. 67:627-630.

Dietrich, R., Ploß, K., and Heil, M. 2004. Constitutive and induced resistance to pathogens in Arabidopsis thaliana depends on nitrogen supply. Plant Cell Environ. 27:896-906.

Duda, F. J. 2008. Suppression of turfgrass diseases through manipulation of soil pH. Nat. Sci. Educ. 37:38-42.
Frank, K. W., O'Reilly, K. M., Crum, J. R., and Calhoun, R. N. 2006. Fate of nitrogen applied to mature in Kentucky bluegrass turf. Crop Sci. 46: 209-215.

Freeman, T. R. 1974. Influence of nitrogen fertilization on severity of Pythium blight of ryegrass. Int. Turfgrass Soc. Res. J. 2:335-338.

Garling, D. C. 2000. The effects of compost topdressing on turf quality, foliar nitrogen concentration and dollar spot severity on creeping bentgrass/annual bluegrass golf course fairways. MSc thesis, The Ohio State University, Columbus, $\mathrm{OH}$

Golembiewski, R., Vargas, J., Jones, A. L., and Detweiler, A. R. 1995. Detection of demethylation inhibitor (DMI) resistance in Sclerotinia homoeocarpa populations. Plant Dis. 79:491-493.

Golembiewski, R. C., and Danneberger, T. K. 1998. Dollar spot severity as influenced by trinexapac-ethyl, creeping bentgrass cultivar, and $\mathrm{N}$ fertility. Agron. J. 90:466-470.

Golf Course Industry. 2015. State of the Industry Report. Accessed 10 October 2018. http://www.golfcourseindustry.com/article/gci0115-golf-state-industryreport-2015/

Golf Course Superintendents Association of America. 2007. Golf Course Environmental Profile, Volume 1. Accessed 24 January 2020. https:// www.gcsaa.org/uploadedfiles/Environment/Environmental-Profile/PropertyProfile/Golf-Course-Environmental-Profile--Property-Report.pdf

Hill, W. J., Heckman, J. R., Clarke, B. B., and Murphy, J. A. 2001. Influence of liming and nitrogen on the severity of summer patch of Kentucky bluegrass. Int. Turfgrass Soc. Res. J. 9:388-393.

Huber, D. M., and Thompson, I. A. 2007. Nitrogen and plant disease. Pages 31-44 in: Mineral Nutrition and Plant Disease. L. E. Datnoff, et al., eds. American Phytopathological Society, St. Paul, MN.

Kreuser, W. C., and Soldat, D. J. 2011. Growing degree-day model to schedule trinexapac-ethyl applications on Agrostis stolonifera golf putting greens. Crop Sci. 51:2228-2236.

Landschoot, P. J., and McNitt, A. S. 1997. Effect of nitrogen fertilizers on suppression of dollar spot disease of Agrostis stolonifera L. Int. Turfgrass Soc. Res. J. 8:905-911.

Latin, R. 2011. A Practical Guide to Turfgrass Fungicides. APS Press, St. Paul, $\mathrm{MN}$.

Lee, H., Bremer, D., Su, K., and Keeley, S. 2011. Relationships between normalized difference vegetation index and visual quality in turfgrasses: effects of mowing height. Crop Sci. 51:323-332.

Littell, R. C., Milliken, G. A., Stroup, W. W., Wolfinger, R. D., and Schabenberger, O. 2006. SAS for Mixed Models, 2nd ed. SAS Institute Inc. Cary, NC.

Liu, H., and Hull, R. 2009. Improving foliar fertilization of turf. Golfdom 65 : 47-50.

Liu, L. X., Hsiang, T., Carey, K., and Eggens, J. L. 1995. Microbial populations and suppression of dollar spot disease in creeping bentgrass with inorganic and organic amendments. Plant Dis. 79:144-147.

Ma, W. C., Brussaard, L., and De Ridder, J. A. 1990. Long-term effects of nitrogenous fertilizers on grassland earthworms (Oligochaeta: Lumbricidae) their relation to soil acidification. Agric. Ecosyst. Environ. 30:71-80.

Markland, F. E., Roberts, E. C., and Frederick, L. R. 1969. Influence of nitrogen fertilizers on Washington creeping bentgrass, Agrostis palustris Huds. II. Incidence of dollar spot, Sclerotinia homoeocarpa, infection. Agron. J. 61 701-705.

Nelson, E. B., and Craft, C. M. 1991. Introduction and establishment of strains of Enterobacter cloacae in golf course turf for the biological control of dollar spot. Plant Dis. 75:510-514

Nelson, E. B., and Craft, C. M. 1992. Suppression of dollar spot on creeping bentgrass and annual bluegrass turf with compost-amended topdressings. Plant Dis. 76:954-958.

Petrovic, A. M. 1990. The fate of nitrogenous fertilizers applied to turfgrass. J. Environ. Qual. 19:1-14.

Pierre, W. H. 1928. Nitrogenous fertilizers and soil acidity. I. Effect of various nitrogenous fertilizers on soil reaction. J. Am. Soc. Agron. 20:254-269.

Pimentel, D., Acquay, H., Biltonen, M., Rice, P., Silva, M., Nelson, J., Lipner, V., Giordano, S., Horowitz, A., and D'Amore, M. 1992. Environmental and economic costs of pesticide use. Bioscience 42:750-760.

Ryan, C. P., Dernoeden, P. H., Grybauskas, A. P., and Momen, B. 2011. Influence of summer spoonfeeding six nitrogen sources on dollar spot severity and chlorothalonil efficacy in creeping bentgrass. Appl Turf Sci. 8:1-9.

Saint-Denis, T., and Goupy, J. 2004. Optimization of a nitrogen analyser based on the Dumas method. Anal. Chim. Acta 515:191-198.

Salgado-Salazar, C., Beirn, L. A., Ismaiel, A., Boehm, M. J., Carbone, I., Putman, A. I., Tredway, L. P., Clarke, B. B., and Crouch, J. A. 2018. Clarireedia: a new fungal genus comprising four pathogenic species responsible for dollar spot disease of turfgrass. Fungal Biol. 122:761-773

Sang, H., Hulvey, J., Popko, J. T., Lopes, J., Swaminathan, A., Chang, T., and Jung, G. 2015. A pleiotropic drug resistance transporter is involved in reduced sensitivity to multiple fungicide classes in Sclerotinia homoeocarpa (F.T. Bennett). Mol. Plant Pathol. 16:251-261.

Smiley, R. W., Dernoeden, P. H., and Clarke, B. B. 2005. Compendium of Turfgrass Diseases, 3rd ed. APS Press, St. Paul, MN 
Soper, D. Z., Dunn, J. H., Minner, D. D., and Sleper, D. A. 1988. Effects of clipping disposal, nitrogen, and growth retardants on thatch and tiller density in zoysiagrass. Crop Sci. 28:325-328

Stiegler, J. C., Richardson, M. D., and Karcher, D. E. 2011. Foliar nitrogen uptake following urea application to putting green turfgrass species. Crop Sci. 51: 1253-1260.

Tomer, V., Sangha, J., and Ramya, H. 2015. Pesticide: an appraisal on human health implications. Proc. Natl. Acad. Sci., India, Sect. B Biol. Sci.85:451-463.
Vargas, J. M. 1994. Management of Turfgrass Diseases, 2nd ed. Lewis Publishers, Boca Raton, FL.

Walsh, B., Ikeda, S. S., and Boland, G. J. 1999. Biology and management of dollar spot (Sclerotinia homoeocarpa); an important disease of turfgrass. HortScience 34:13-21.

Williams, D. W., Powell, A. J., Jr., Vincelli, P., and Dougherty, C. T. 1996. Dollar spot on bentgrass influenced by displacement of leaf surface moisture, nitrogen, and clipping removal. Crop Sci. 36:1304-1309. 